\title{
THE ESTUARINE BENTHIC DIATOM Margaritum terebro (BACILLARIOPHYTA, HYALODISCACEAE): MORPHOLOGY AND TAXONOMY
}

\author{
Roseli M. de Souza-Mosimann'; Luciano F. Fernandes ${ }^{2}$ \& Thelma V. Ludwig ${ }^{2}$ \\ ${ }^{1}$ Universidade Federal de Santa Catarina \\ Horto Botânico - Campus Universitário, Trindade \\ (Caixa Postal 476, 88040-900 Florianópolis, SC, Brasil) \\ ${ }^{2}$ Universidade Federal do Paraná, Setor de Ciências Biológicas \\ Departamento de Botânica, Centro Politécnico \\ (Caixa Postal 19031, 81531-970 Jardim das Américas, Curitiba, PR, Brasil)
}

- Abstract: Margaritum terebro is an estuarine centric diatom recorded along the southeast coast of Brazil, the Atlantic coast of Africa, and in regions close to the Galapagos Islands. Previous works only give a very limited information on the morphology and taxonomy of the genus based on light microscope. In this work, the species is described with scanning electron microscope. Results show a valvar surface with specific structures such as external projections of the rimoportulae bearing a central pore and convex sides. The internal openings are sessile. The term rimoportulae "papilliformis" is proposed for this new structure. The margin of the valve is undulated and presents a ring of sessile rimoportulae and spines irregularly arranged. Comparisions between the monospecific genus Margaritum and other related genera (Podosira and Hyalodiscus), and its systematic positioning are made.

- Resumo: Margaritum terebro é uma diatomácea marinha estuarina registrada apenas para a costa sul-brasileira, costa atlântica da África e adjacências das Ilhas Galápagos. Os trabalhos publicados até o momento referem-se apenas à morfologia da valva sob microscopia ótica, pouco esclarecendo sobre a posição taxonômica do gênero. No presente trabalho, a espécie é descrita sob microscopia eletrônica de varredura a partir de amostras de plâncton e perifiton de águas neríticas do sul do Brasil. Os resultados revelam uma superfície valvar provida de rimopórtulas características com projeções externas robustas, poro central e lados convexos; na superficie interna sua abertura é séssil. O termo rimopórtula "papilliformis" é proposto para este tipo inédito de rimopórtula. As estrias são constituídas por estruturas semelhantes a espinhos. A margem valvar é ondulada e apresenta um anel de rimopórtulas sésseis e espinhos irregularmente arranjados. Comparações entre o gênero monoespecífico Margaritum e gêneros próximos (Podosira e Hyalodiscus) permitiram posicioná-lo convenientemente na Família Hyalodiscaceae Crawford.

- Descriptors: Margaritum, Diatom, Hyalodiscaceae, Taxonomy, Estuarine, Periphyton, Southern Brazil.

- Descritores: Margaritum, Diatomácea, Hyalodiscaceae, Taxonomia, Estuarina, Perifiton, Sul do Brasil. 


\section{Introduction}

The centric marine diatom Margaritum terebro (Leuduger-Fortmorel) H. Moreira originally described as Podosira terebro by LeudugerFortmorel (1898), was transferred to the new genus Margaritum by Moreira-Filho (1968) based on the presence of "pearl shaped" structures or "hemispheres" on the external surface of the valve; they do not occur in other genera, including those closely related, such as Hyalodiscus, Melosira and Podosira. In 1969, Dr. G. Dallas Hanna from the California Academy of Sciences and Dr. N.I. Hendey sent letters to Dr. Moreira-Filho to express the acceptance of Dr. Moreira-Filho's proposal of the new genus. As pointed out by Hendey (1971), the specific epithet was misspelled by Moreira-Filho as "tenebro".

Margaritum terebro is an estuarine species that has been recorded along the southeast coast of Brazil (Moreira-Filho, 1968; Souza-Mosimann, 1988; Fernandes et al., 1990), the Atlantic coast of Africa (Leuduger-Fortmorel, 1898; Hendey, 1958) and in the proximity of the Galapagos Islands (Hendey, 1971). These findings suggest that the species is restricted to tropical regions.

Some research on this species has been done through light microscopy, but failed to detail the morphology and taxonomy of the genus. Until now, its position in the classification of Round et al. (1990) was uncertain, because the internal valvar surface and the cingulum structure were not described.

Recently, periphyton samples collected in Paranaguá Bay (Paraná State, Brazil) contained a reasonable amount of Margaritum terebro cells and permitted a more detailed study of its morphology based on scanning electron microscopy observations, elucidating the taxonomic affinities between Margaritum and other genera, besides placing it conveniently in higher taxonomic categories. The relationships between Margaritum and related genera such as Podosira and Hyalodiscus are also presented and a new type of rimoportula is described.

\section{Material and methods}

Samples containing the species Margaritum terebro were obtained from periphyton on glass slides and from plankton samples in Paranaguá Bay, Paraná state, Southern Brazil $\left(25^{\circ} 27^{\prime} \mathrm{S}, 48^{\circ} 20^{\prime} \mathrm{W}\right)$. Permanent slides and the original material examined were deposited in the FLOR Herbarium at Federal
University of Santa Catarina (UFSC), number 12.759 .

Samples were preserved with buffered formaldehyde (2\%) and prepared for light and electron microscopy according to the method described by Hasle \& Fryxell (1970). Permanent slides were prepared using Permount as the mounting media. Light microscopy (LM) was performed with an Olympus BX40 microscope using $100 \mathrm{x}$ oil immersion objective. For scanning electron microscopy (SEM) samples were airdried onto coverslips and mounted on aluminium stubs with conductive paint, coated with gold 16$20 \mathrm{~nm}$ thick and examined at $15-30 \mathrm{Kv}$ accelerating voltage in a Phillips model XL30 scanning electron microscope.

The descriptive terminology followed that of Ross et al. (1979) and Round et al. (1990).

\section{Results}

\author{
Division Bacillariophyta \\ Class Coscinodiscophyceae Round \& Crawford \\ Subclass Coscinodiscophycidae Round \& Crawford \\ Order Melosirales Crawford \\ Family Hyalodiscaceae Crawford \\ Genus Margaritum H. Moreira \\ Species M. terebro (Leuduger-Fortmorel) \\ H. Moreira
}

Description LM: Cells are spherical; plastids are disk-like and circular. Valves circular, $30 \mu \mathrm{m}$ to $50 \mu \mathrm{m}$ in diameter (120 valves measured); valvar surface deeply convex, with hemispheric projections arranged in diagonal rows (Fig. 1). Spines are scattered on the surface, visible as refringent small spots forming concentric striae (Fig. 1). Radial rows of areolae are visible under Phase-contrast illumination (Fig. 2). Valvar margin thick, forming an undulation separated by a concavity (Fig. 3).

Description SEM: Frustules are robust, almost spherical; valvar diameter slightly larger than the pervalvar axis (Fig. 4). Valve is convex; valvar surface provided of small hollow spines (Figs 6-7). External projections of rimoportulae are arranged in concentric diagonal rows (Figs 5-6). Each rimoportula is formed by a robust external projection of approximately irregular morphology (almost polygonal and rounded) (Fig. 7) and a central pore that opens to the inside of the valve through a small slit surrounded by a circular thickened rim (Fig. 12). For this type of rimoportula we propose the term 
rimoportula "papilliformis". The valvar margin presents a thickened undulation projected outward and includes a ring of rimoportulae lacking external projections (Figs 4, 6, 9). The internal valvar surface possesses openings of rimoportulae and foramina (Figs 11-13). The foramina are circular with slightly thickened edges, and arranged in radial rows (Figs 10-13). As the basal siliceous layer is thickened, the foramina clearly form elongated channels through it

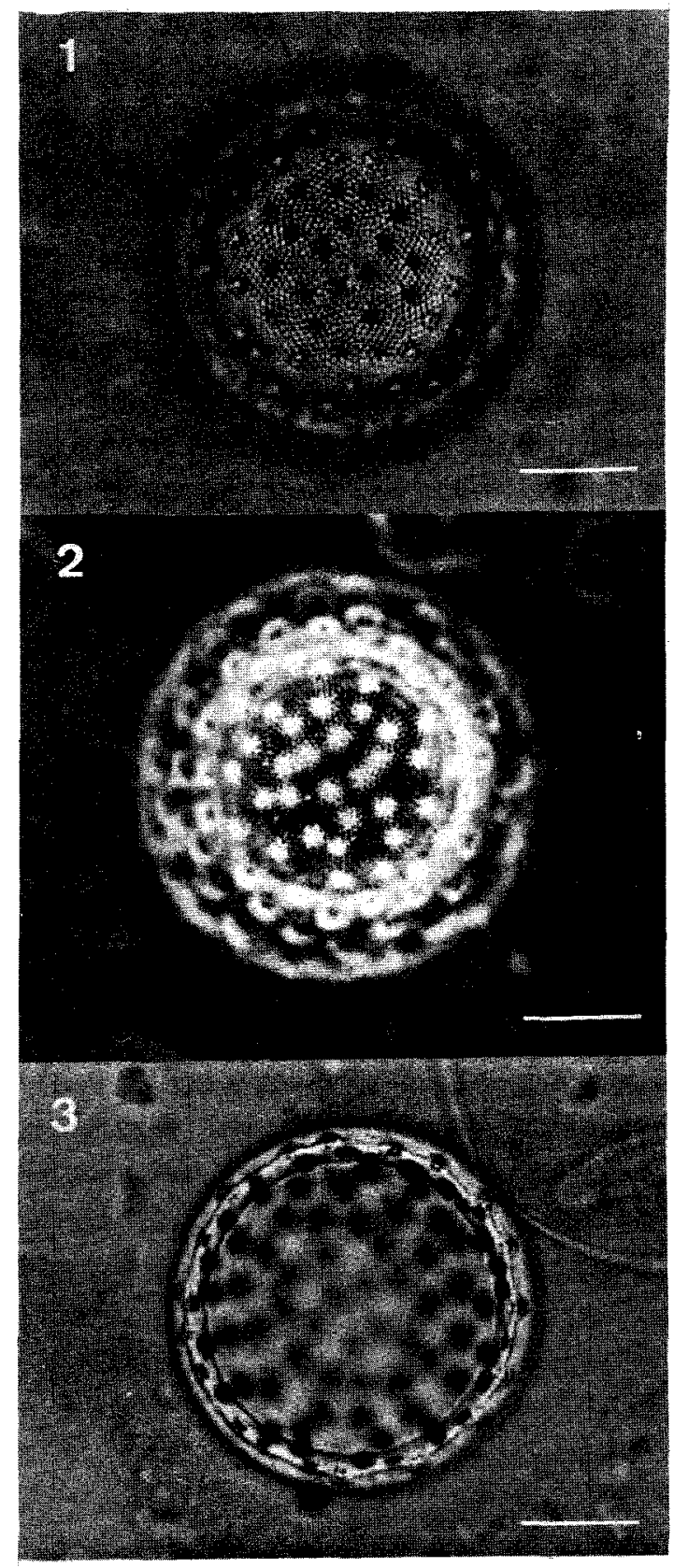

(Fig. 14). Areolae loculate lacking rotae, nonbululate (Fig. 14). The valvar edge is thickened, slightly concave, and its borders show a small groove. Cingulum is composed of 4-5 narrow bands. Each copula is formed by a longitudinal smooth ring and numerous longitudinal pores (Figs 8-9); ligulae were not observed.

Figs 1 - 3. Margaritum terebro, Light microscope, valve views. Scale bar $=10 \mu \mathrm{m}$. Fig. 1. Upper focus showing rimoportulae papilliformis and disposition of spines. Fig. 2. Upper focus under phase-contrast. Fig. 3. Lower focus showing a side view of the rimoportulae near the margin. 


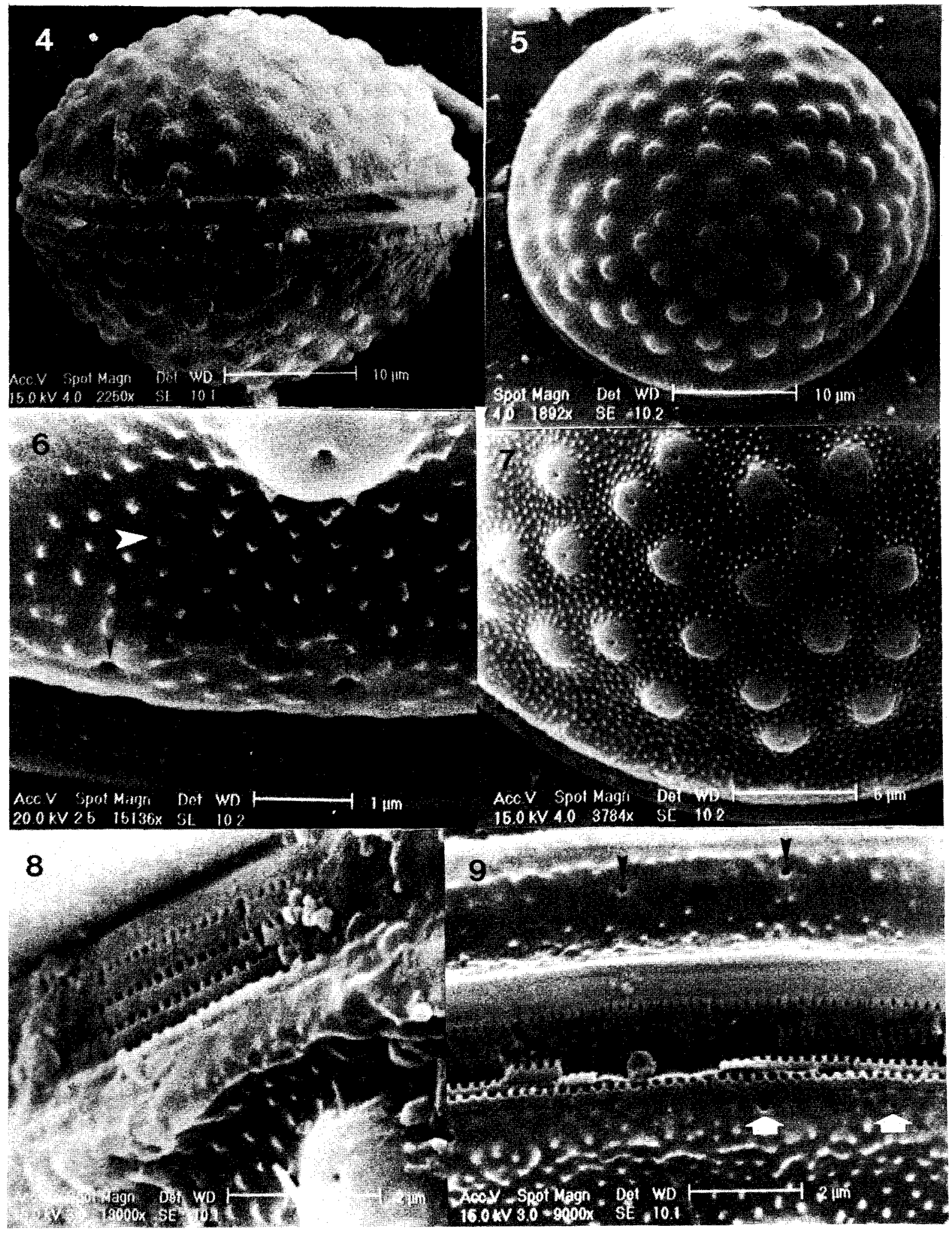

Figs. 4 - 9. Margaritum terebro, SEM, external views. Fig. 4. Lateral view of the frustule. Valvar diameter is slightly larger than pervalvar axis. Arrowhead indicates the undulation of the valve. Scale bar $=10 \mu \mathrm{m}$. Fig. 5 . Oblique orientation of a valve illustrating the disposition of the rimoportulae. Scale bar $=10 \mu \mathrm{m}$. Fig. 6. Detail of an undulation showing two sessile external apertures of rimoportulae (arrowheads). Note the spines on the surface. White arrowhead indicates a broken spine. Scale bar $=1 \mu \mathrm{m}$. Fig. 7. Morphology of rimoportulae on the external side. Each projection is approximately polygonal with a central aperture. Many refringent spines are scattered over the valve. Scale bar $=5$ $\mu \mathrm{m}$. Fig. 8. Detail of an intact cingulum showing four bands. Scale bar $=2 \mu \mathrm{m}$. Fig. 9. Lateral view of a frustule to show the cingulum and undulations of the valves. Arrowheads and white arrows indicate the undulations bearing sessile apertures of rimoportulae. Scale bar $=2$ $\mu \mathrm{m}$. 


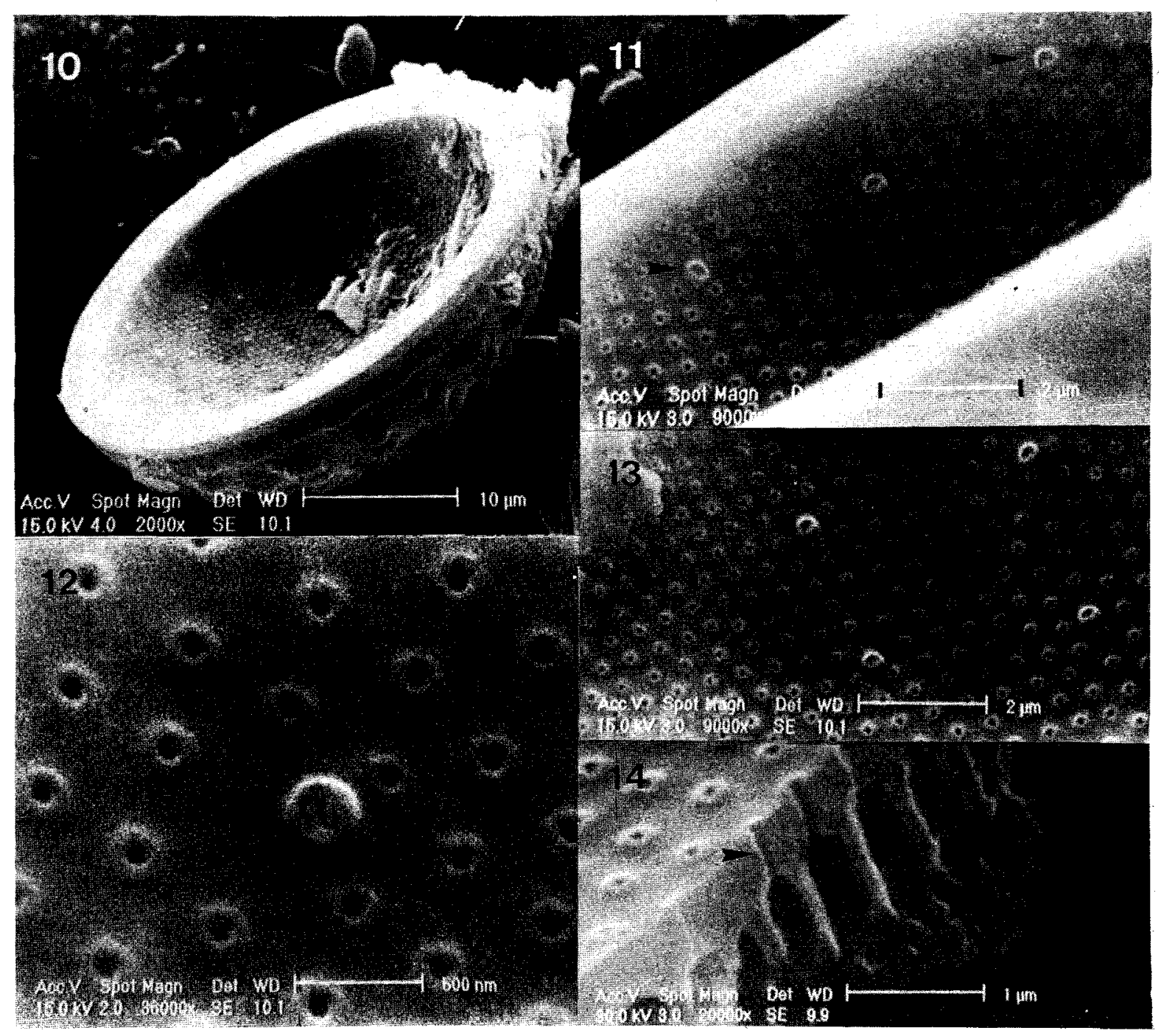

Figs. 10 - 14. Margaritum terebro, SEM, internal view. Fig. 10 . General view of the valve. Scale bar $=10 \mu \mathrm{m}$. Fig. 11. Detail of the valvar margin with three rimoportulae aligned to form a ring (arrowheads). Note areolae in radial rows. Scale bar= $2 \mu \mathrm{m}$. Fig. 12. Internal structure of a rimoportula. Scale bar $=500 \mathrm{~nm}$. Fig. 13. Disposition of the rimoportulae on the surface (except for the valvar margin; see Fig. 11). Scale bar $=2 \mu \mathrm{m}$. Fig. 14. Broken valve showing non-bululate areolae. Arrowhead indicates an elongated foramen. Scale bar $=1 \mu \mathrm{m}$.

\section{Discussion}

The main feature of Margaritum terebro is the unusual external aperture of each rimoportula, which is robust and polygonal. It was named "hemispherical projections" by Moreira-Filho (1968) and "wart-like structures" by Hendey (1958, 1971). Its morphology does not fit into any of the known types of rimoportulae (Hasle, 1972; Ross et al., 1979; Round et al., 1990), and therefore we propose the term rimoportula "papilliformis" for this new type. In addition, the 
marginal ring of rimoportulae, and the undulation of the valve make the species well distinct from others. In order to better circumscribe the genus Margaritum some comparisons with related genera were made. Table 1 summarizes the main features of the genus Margaritum compared with the genera Hyalodiscus and Podosira.

The genus Podosira does not poses a marginal ring of rimoportulae, as seen in the genus Margaritum. On the valvar surface of Podosira the rimoportulae occur in greater numbers and are not ordered. Moreover, their external openings are sessile, i.e., lacking projections. In Margaritum the rimoportulae are ordered and characteristic (papilliformis). The foramina of the areolae are arranged in radial rows and lack rotae. Observations of the areolar structure in Podosira by Round et al. (1990) showed rotae occluding foramina. Furthermore, these authors recorded no defined pattern in the areolar disposition, and closely packed areolae. The minute external pores of the areolae, as cited by Round et al. (op. cit.) for Podosira were not present, or were not discernible in our samples of Margaritum with SEM. In relation to the spines, these structures have not yet been found in Podosira, although they have been observed in Margaritum.

On the other hand, both genera show nonbululate areolae that, as suggested by Round et al. (op. cit.), could be a potential criterion of separation between Hyalodiscus, Margaritum and Podosira. Copulae are also similar, although less developed in Margaritum, with 4-5 bands. Judging by the location of the copulae and the structure of the margin edge, it is likely that the species presented 2 cells joined by the cingulum, as in the case of Podosira. However, we were not able to find any specimen forming cell diplets in preserved samples.

The genus Hyalodiscus shows characteristics that are not present in Margaritum as a conspicuous central area and bullulate areolae (closely packed). In addition, the rimoportulae of Hyalodiscus show differences in morphology regarding to Margaritum, although a marginal ring of rimoportulae is present in both genera. Stidolph (1993) describes the species $H$. pustulatus A. Schmidt under SEM reporting ligulate open bands, spinules, peculiar baciliform structures on the inner side of the valve, and microlabiate processes. However, the species shows dissimilarities when compared with more typical representatives like $H$. subtilis and $H$. scoticus. Indeed, it seems to bear characteristics of Melosira Agardh, as special loculate areolae with external ridges encircling the pores, granules, spines and bands of cingulum (see figures 12, 13 and 23 of Stidolph, 1993).
We decided to place the genus Margaritum within the Family Hyalodiscaceae, because its frustule morphology is more closely related to those of Podosira and Hyalodiscus. For instance, in all of them the loculate areolae and/or the disposition of the rimoportulae are similar.

As demonstrated from the SEM study in the present work, we support the maintenance of the genus Margaritum as first proposed by MoreiraFilho (1968), due to the presence of typical rimoportulae papilliformis, marginal ring of rimoportulae (as in Hyalodiscus) and the nonbullulate areolae and bands of the cingulum (as in Podosira).

Margaritum terebro has been found in estuarine environments from tropical regions of the World. It was collected from the stomachs of benthic invertebrates (Leuduger-Fortmorel, 1898; Valente-Moreira et al., 1994), epiphytic on macroalgae (Moreira-Filho \& ValenteMoreira, 1980, 1981; Valente-Moreira et al., 1980; Moreira-Filho et al., 1990), and from the sand gravels of intertidal zones (Hendey, 1958 and 1971). In the present study the species was fairly common on glass slides used to analyze the seasonal dynamics of the periphyton in the Paranaguá Bay (Brandini, pers. com.*). All of these findings lead us to believe that $M$. terebro grows in a benthic habitat, an environment that could be a unifying characteristic among the representatives of the Family Hyalodiscaceae. Other authors have encountered $M$. terebro in plankton samples, but always in shallow, turbulent regions of the sea (Fernandes et al., 1990; Moreira-Filho et al., 1975; Souza-Mosimann, 1984, 1985 and 1988; Souza-Mosimann et al., 1989).

\section{Acknowledgements}

We thank COPEL (Companhia Paranaense de Energia Elétrica), and to Dr. Maurício P. Cantão (LAC) and Dra. Daura R. Stofella (CME/UFPR) for the use of the SEM; to Dr. J. P. Kocioleck (California Academy of Sciences) who kindly sent some papers. Our gratitude to Jones $J$. Bastos for his photographic work. The anonymous referees improved the manuscript of this paper.

(*)Brandini, F. P. Universidade Federal do Paraná. Centro de Estudos do Mar. 
Table 1. Comparative morphology between the Genus Margaritum and the related Genera Hyalodiscus and Podosira. (1) from Round et al. (1990).

\begin{tabular}{|c|c|c|}
\hline Margaritum & Hyalodiscus $^{1}$ & Podosira \\
\hline $\begin{array}{l}\text { external apertures of the } \\
\text { rimoportulae projected, characteristic } \\
\text { (papilliformis) }\end{array}$ & $\begin{array}{l}\text { external apertures of the } \\
\text { rimoportulae inconspicuous }\end{array}$ & $\begin{array}{l}\text { external apertures of the } \\
\text { rimoportulae inconspicuous }\end{array}$ \\
\hline
\end{tabular}

internal apertures of the rimoportulae single and sessile with a longitudinal slit

presence of a marginal ring of rimoportulae

non bullulate areolae

spines on the valvar surface

central area absent

bands of cingulum open (?)

areolar pores not evident on outer surface (present ?) similar

similar presence of a marginal ring of rimoportulae

bullulate areolae

no spines

central area large, evident

bands of cingulum open (?)

areolar pores evident, arranged in rows marginal ring of rimoportulae absent

non bullulate areolae

no spines

central area absent

bands of cingulum open

areolar pores minute, hardly visible with SEM

\section{References}

Fernandes, L. F.; Souza-Mosimann, R. M. de \& Felício-Fernandes, G. 1990. Diatomáceas (Bacillariophyceae) do Rio Ratones, Florianópolis, SC, Brasil: baixo curso e estuário. Insula, 20:11-112.

Hasle, G. R. \& Fryxell, G. A. 1970. Diatoms: cleaning and mounting for light and electron microscopy. Trans. Am. micros. Soc., 89:469474.

Hasle, G. R. 1972. Two types of valve processes in centric diatoms. Nova Hedwigia, 39:55-78.

Hendey, N. I. 1958. Marine diatoms from some west African ports. J. R. microsc. Soc., 77(1/2):2885.

Hendey, N. I. 1971. Some marine diatoms from the Galapagos Islands. Nova Hedwigia, 22:(1/2), 371-422.
Leuduger-Fortmorel, G. 1898. Diatomées marines de la cote occidentale d"Afrique. Mém. Soc. Emulat. Côtes Nord, p. 1-41. 8 pls.

Moreira-Filho, H. 1968. Margaritum (Podosira) tenebro (Leuduger-Fortmorel) Nov. Genus et nova comb. Bolm Univ. Fed. Paraná, Bot., $20: 1-4$.

Moreira-Filho, H., Valente-Moreira, I. M. \& TripiaCecy, I. 1975. Diatomáceas da Baía de Paranaguá, Estado do Paraná, Brasil (Chrysophyta-Bacillariophyceae). Bolm Mus. Bot. Munic., 20:1-25.

Moreira-Filho, H. \& Valente-Moreira, I. M. 1980. Diatomáceas epífitas em Ulva fasciata Delile. Bolm Mus. Bot. Munic., 41:1-10.

Moreira-Filho, H. \& Valente-Moreira, I. M. 1981. Avaliação taxonômica e ecológica das diatomáceas (Bacillariophyceae) epífitas em algas pluricelulares obtidas nos litorais dos Estados do Paraná, Santa Catarina e São Paulo. Bolm Mus. Bot. Munic., 47:1-17. 
Moreira-Filho, H. \& Valente-Moreira, I. M.; SouzaMosimann, R. M. de \& Cunha, J. A. 1990. Avaliação florística e ecológica das diatomáceas (Chrysophyta-Bacillariophyceae) marinhas e estuarinas nos Estados do Paraná, Santa Catarina e Rio Grande do Sul. Est. Biol., 25:548.

Ross, R.; Cox, E. J.; Karayeva, N. I.; Mann, D. G.; Paddock, T. B. B. ; Simonsen, R. \& Sims, P. A. 1979. An emended terminology for the siliceous components of the diatom cell. Nova Hedwigia, 64:513-533.

Round, F. E.; Crawford, R. M. \& Mann, D. G. 1990. The diatoms. Biology and morphology of the genera. Cambridge, Cambridge University Press. 747p.

Souza-Mosimann, R. M. de 1984. Levantamento preliminar das diatomáceas (ChrysophytaBacillariophyceae) na região de Anhatomirim, Santa Catarina, Brasil. Insula, 14:2-46.

Souza-Mosimann, R. M. de 1985. Contribuição ao conhecimento das diatomáceas (ChrysophytaBacillariophyceae) em algu-mas estações localizadas na Baía Norte, Florianópolis, Santa Catarina, Brasil. Insula, 15:3-31.

Souza-Mosimann, R. M. de 1988. Estudo das diatomáceas (Chrysophyta Bacillariophyceae) da Baía Sul, Florianópolis, Santa Catarina, Brasil. Insula, 18:23-74.
Souza-Mosimann, R. M. de; Felício-Fernandes, G. \& Fernandes, L. F. 1989. Contribuição ao conhecimento das diatomáceas da Baía de Tijucas, Santa Catarina, Brasil. Insula, 19:95122.

Stidolph, S. R. 1993. A light and electron microscopical study of Hyalodiscus pustulatus A. Schmidt (Bacillariophyceae) from New Zeland marine habitats. Bot. Mar., 36(2):7986.

Valente-Moreira, I. M.; Moreira-Filho, H.; Cunha, J. A. \& Ludwig, T. A. V. 1980. Diatomáceas epifitas em Padina vickersiae Hoyt ex Howe. Trib. Farmac., 48 (1-2):114-122.

Valente-Moreira, I. M.; Moreira-Filho, H. ; Cunha, J. A. \& Nakamura, I. T. 1994. Diatomáceas (Chrysophyta-Bacillariophyceae) no conteúdo estomacal de peixes e crustáceos do manguezal do rio Perequê, Pontal do Sul, Estado do Paraná, Brasil. Est. Biol., 3:99-114.

(Manuscript received 29 August 1997; revised 28 November 1997; accepted 20 December 1997) 